\title{
Monitoring on impact of insecticides on mortality of honey bees (Apis mellifera L.) in front of beehives
}

\author{
Pashte Vrushali Vijaykumar ${ }^{1 *}$ and Patil Chidanand Shivshankar ${ }^{2}$ \\ ${ }^{1}$ Department of Entomology, Post Graduate Institute, Mahatma Phule Krishi Vidyapeeth, Rahuri, Ahmednagar- \\ 413722 (Maharashtra), INDIA \\ ${ }^{2}$ Pesticide Residue Laboratory, Department of Entomology, Post Graduate Institute, Mahatma Phule Krishi \\ Vidyapeeth, Rahuri, Ahmednagar-413722 (Maharashtra), INDIA \\ *Corresponding author. E-mail: pashte.vrushali@gmail.com
}

Received: July 5, 2016; Revised received: February 3, 2017; Accepted: April 28, 2017

Abstract: The present study investigated effect of pesticide usage and public awareness on honey bee mortality. The experiments were conducted at three different sites at Maharashtra, India with domesticated bee hives of Apis mellifera $\mathrm{L}$. The maximum bee mortality during $51^{\text {st }}$ week of $2012-13$ (1559.10 bees/hive/week) clearly indicated towards the direct and indirect effect of insecticides in general at study site I (Case I). Similar experiments were repeated at other two different sites during 2013-14. Farmers (Case II and III) were aware of beekeeping and ill effects of pesticides. Farmers followed some precautionary measures to combat with the bad effect of insecticides on bees. As a result there was less mortality of bees. The experiments revealed that farmers should be aware of bee conservation and precautionary measures to combat with the bad effect of insecticides on bees.

Keywords: Bee mortality, Honey bee, Insecticide, Survey

\section{INTRODUCTION}

Wild as well as domesticated bees are major component of terrestrial ecosystem. Many plants would be unable to complete their development cycle without the intervention of pollinators

(Klein et al., 2007). Bees act as a vital pollinator for many plants and have well known optimistic impact on the crop production due to their foraging activity (Pashte and Said, 2015; Pashte and Kulkarni, 2015). In addition honey bees have other positive impact, including the production of honey, propolis, royal jelly, maintain genetic diversity in plants and act as a bio-indicator (Porrini et al., 2003). Bee heath is receiving increased attention as bee populations are declining worldwide (VanEgelsdorp et al., 2008). Use of insecticides is being one of the promising causes for the bee deaths (Potts et al., 2010). Concern about adverse effects of pesticides on honey bees have been the subject of research and debate. Many workers were recorded bee mortality near or in front of hive because of direct or residual pesticide toxicity (Mayer and Johansen, 1983; Delabie et al., 1985; Celli et al., 1989; Perez et al., 2001; Steen and Dinter, 2007). The main goal of this field study was to investigate the potential impact of insecticides usage which is widely used by the farmers for insect management on honey bee (A. mellifera) mortality.

\section{MATERIALS AND METHODS}

The experiments were conducted for two years. During the year 2012-2013, the experiment was conducted at horticultural division, Mahatma Phule Krishi Vidyapeeth (M. P. K. V.), Rahuri, Maharashtra, India $\left(19.35^{\circ} \mathrm{N}\right.$ and $74.65^{\circ} \mathrm{E}$ ), where ten colonies of honey bees were kept under the supervision. The period of monitoring was from September 2012 to January 2013, the usual blooming period of most of the horticultural and field crops. In all, ten bee colonies with $5 \mathrm{~m}$ distance between two colonies were provided with dead bee tray in front of colonies. The plastic trays $(40 \times 30 \mathrm{~cm})$ were used for this purpose. A thick band of grease was applied to the outer border of trays for protection of dead bees from ants. The trays were provided with a cover of metal mesh (mesh size-1 inch).

The count on dead bees observed in the tray kept in front of colonies was recorded thrice in each week during morning hrs (10.00-11.00 AM). Collected dead bees were disposed off after counting. All bee colonies were under supervision of trained person for the maintenance of bee colonies. Fortnightly observations were recorded on the pest and disease incidence and number of frames with bees.

Data on pesticide usage by different research projects in the periphery of $3 \mathrm{~km}$ from apiary (10 bee hives) were collected during the experimental period (Case I). Similar experiments were conducted at two other locations (Case II and III) during 2013-14. Details of location of the experimental site are given in Table 1 . The observed bee mortality data were analysed by 
using Kruskal-Wallis test (McDonald, 2014).

Nature of season during experimental period: The metrological data on important weather parameters during the experimental period was recorded at meteorological observatory of the Mahatma Phule Krishi Vidyapeeth, Rahuri (Maharashtra), India.

\section{RESULTS AND DISCUSSION}

Mortality of honey bees observed in front of colonies at Horticulture Division, Mahatma Phule Krishi Vidyapeeth, Rahuri (Case I): Foraging behaviour is the link between the bee colony and the environment. Besides collecting pollen, nectar, water and resin, this has significant importance for plant pollination. As such foraging activity is very important as a bioindicator for indirect studies of environmental contamination with insecticides. Studies were undertaken comprising case I with lack of coordination and case II and case III with proper coordination on farmer's field.

Monitoring studies were carried out in the M.P.K.V. premises, focusing on the mortality of honey bees in front of the hives. The foraging activity of the honey bee colonies at the test site was not directly measured. It was assumed, based on the honey bee biology, that bee placed in the flowering orchards forage as nearly as possible (A. mellifera foraging range: $2-3 \mathrm{~km}$ ) and that the M.P.K.V. was rich source of flowering plants attractive to bees. The consideration of the meteorological data also supported the hypothesis about the bee activity.

The mortality of $A$. mellifera observed from $35^{\text {th }}$ week to $45^{\text {th }}$ week was normal [(Normal mortality for a colony with 60000 bees/colony: $<100$ bees/day), Abrol, 2009]. During $46^{\text {th }}$ and $47^{\text {th }}$ week, there was marginal increase in mortality as compared to earlier two months as 46.40 bees/hive/week and 56.00 bees/hive/ week, respectively. However there was significant mortality (level of significance- $0.05 \%$ ) of $A$. mellifera in front of bee hives (A to $\mathrm{J}$ ) during $48^{\text {th }}$ week of the year 2012 (Table 2). Subsequently, bee mortality increased leading to more bee population loss during $49^{\text {th }}$ to $50^{\text {th }}$ week as 960.70 and 887.80 bees/hive/week, respectively. The maximum bee (Apis mellifera L.) mortality during $51^{\text {st }}$ week (1159.10 bees/hive/week).

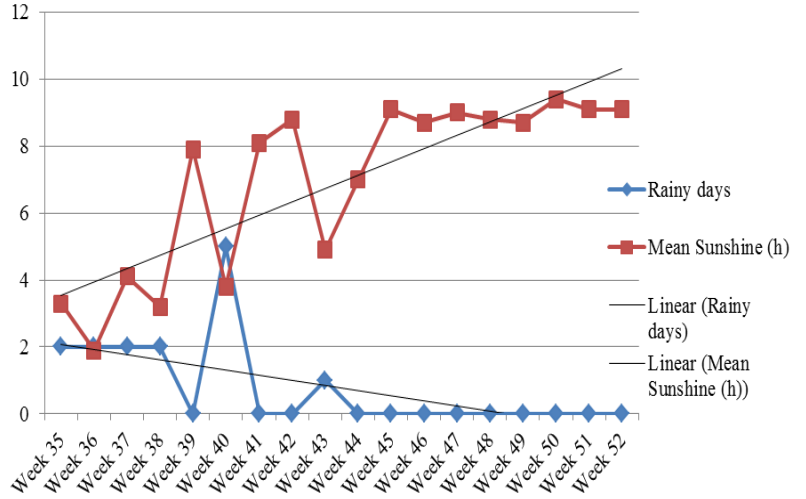

Fig. 1. Status of rainfall and sunshine hours during the observation period (Case I).

During $52^{\text {nd }}$ week and $53^{\text {rd }}$ week, the mean bee mortality was declined due to less population inside the hives. More than 90 per cent of dead bees showed abnormal symptoms.

While monitoring bee deaths, the population inside the hives was observed for the presence of bee disease incidence and population density by recording number of frames with bee cluster. During $35^{\text {th }}$ to $37^{\text {th }}$ week, all the bee colonies were with healthy bee population of 9 -8 frames/hive. However, during $49^{\text {th }}$ to $53^{\text {rd }}$ week the drastic reduction was observed in the bee population. During $49^{\text {th }}$ and $51^{\text {st }}$ week, the mean number of frames with bees/hive were 4.50 and 1.30 , respectively. During $53^{\text {rd }}$ week $\left(1^{\text {st }}\right.$ week of 2013$)$ all the bee hives were empty.

The meteorological data indicated that there was no rainfall but increase in sunshine hours after $44^{\text {th }}$ week (Fig.1). The favourable environmental conditions supported more foraging hours and more exposure of bees to the different crops. The environmental factors such as temperature, humidity, rainfall and wind greatly influenced foraging activity of honey bees (AbouShaara, 2014). At ambient temperatures of about 20-30 ${ }^{\circ} \mathrm{C}$, the highest foraging activity was recorded (Tan et al., 2012), while the low-est foraging activity was found at $43^{\circ} \mathrm{C}$ (Blazyte-Cereskiene et al., 2010) as well as at or below $10^{\circ} \mathrm{C}$ (Joshiand Joshi, 2010). Higher humidity, rainfall, wind and low temperature had negative impact on bee visits (Puskadija et al., 2007). However, the exact foraging activity of honey bees

Table 1. Details of honey bee colonies with locations observed for bee mortality.

\begin{tabular}{|c|c|c|c|c|c|}
\hline S. $\mathbf{N}$. & Name of Location & Owner/Farmer & Bee species & $\begin{array}{c}\text { Foraging crop } \\
\text { and area }\end{array}$ & $\begin{array}{c}\text { Period of } \\
\text { observation }\end{array}$ \\
\hline 1 & $\begin{array}{l}\text { Horticultural } \\
\text { M.P.K.V., Tarm, } \\
\text { Ahmednagar (M.S.) }\end{array}$ & $\begin{array}{l}\text { Directorate of Beekeep- } \\
\text { ing, Mahabaleshwar, } \\
\text { KVIC (M.S.) }\end{array}$ & A. mellifera & $\begin{array}{l}\text { Multiflora } \\
\text { (30 ha) }\end{array}$ & $\begin{array}{l}\text { August 2012- } \\
\text { January } 2013\end{array}$ \\
\hline 2. & $\begin{array}{l}\text { Chanda, Taluka- Nevasa, } \\
\text { Ahmednagar (M.S.) }\end{array}$ & Mr. Dahatonde V. & A. mellifera & $\begin{array}{l}\text { Pomegranate } \\
\quad(6 \text { ha })\end{array}$ & $\begin{array}{l}\text { October 2013- } \\
\text { December } 2013\end{array}$ \\
\hline 3. & $\begin{array}{l}\text { Aalefata, Taluka- Narayan- } \\
\text { gao, Pune (M.S.) }\end{array}$ & Mr. Kuhrade S. G. & A. mellifera & $\begin{array}{l}\text { Pomegranate } \\
(10 \mathrm{ha})\end{array}$ & $\begin{array}{c}\text { November } 2013- \\
\text { February } 2014 \\
\end{array}$ \\
\hline
\end{tabular}

Multiflora $^{*}=$ Grape, Guava, Pomegranate, Custard Apple, Ber, Anola, Pigeon Pea, Chick Pea, Cotton, Sorghum, Vegetables: Bhendi, Wal, Brinjal, Chilli, Bitter Gourd, Tomato, Garlic, Cabbage, Cauliflower, Sponge gourd, Green Pea, Onion 


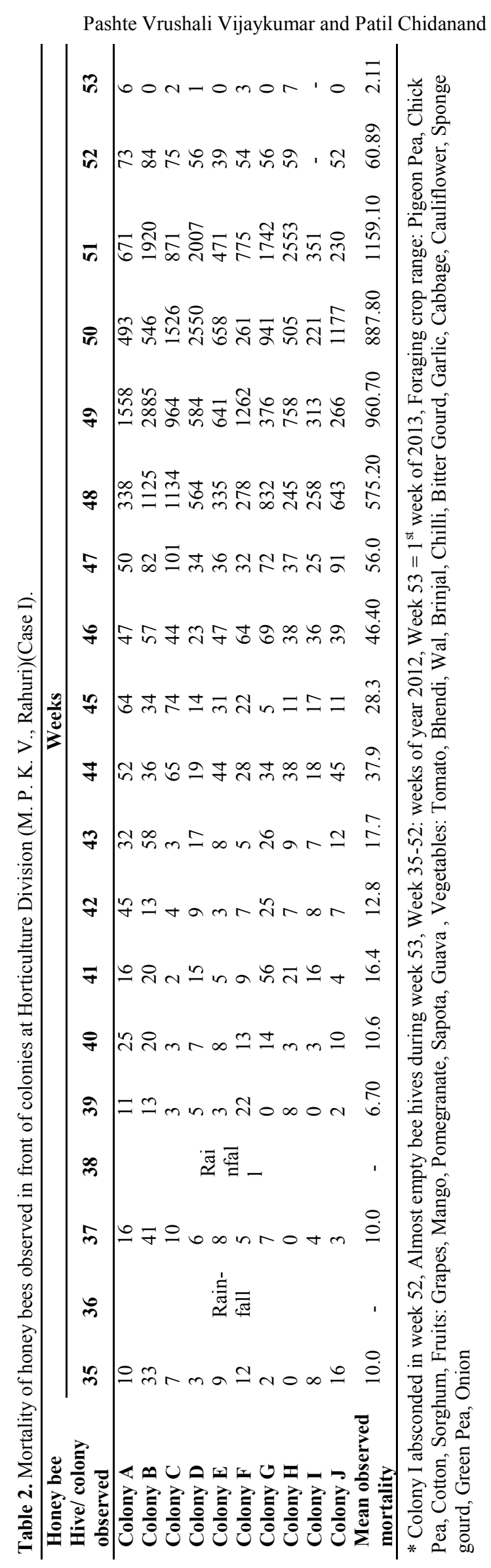

was not monitored during the present experimental period.

The data regarding pesticide usage of various research projects at M. P. K. V., Rahuri was collected for the experimental period (Sept. 2012- Dec. 2012). The data revealed that organophosphorus insecticides ranked first with 38.85 per cent followed by newer insecticides excluding neonicotinoids (26.62\%), synthetic pyrethroids $(16.55 \%)$, neonicotinoids $(13.67 \%)$ and carbamates $(4.32 \%)$ (Table 3 ).

The diverse cropping ecosystem supported more foraging hours and more exposure of bees to the different crops. However, being an experimental crop area M. P. $\mathrm{K}$. V, Rahuri, pesticides were frequently used to manage pests. In the present investigation, drastic reduction in bee population was due to mortality of bees in front of colonies which could be attributed to peak period of pesticide spray interventions on different foraging flowering plants. This clearly indicated the direct and indirect effect of pesticides in general. However, bee mortality in front of colonies could not be attributed to any specific pesticide.

The pesticides have detrimental effects on managed honey bee colonies and their productivity (Schenbayoand Goka, 2016). The evidence of bee deaths in front of colonies was a result of pesticidal poisoning, which was in conformity with earlier reports (Pongthep, 1990; Radunz et al., 1996; Abrol, 2009; Hoven et al., 2013, Anonymous, 2013). Some authors observed abnormal dead bees due to pesticidal toxicity (Abrol, 2009, Mayer et al., 1999; Muthuraman, 2000, Suhail et al., 2001).

Mortality of honey bees observed in front of colonies at Chanda (Case II): An experiment was repeated at Chanda during the year 2013-14, where pomegranate grower maintained $A$. mellifera colonies. The data was recorded on bee mortality during flowering period of pomegranate from 14-10-2013 to 11-122013. The mean mortality of $A$. mellifera bees per day ranged between 0-32.50 dead bees/day. The pomegranate orchard was sprayed twice with azadirachtin 0.03 $\%$ @ 5ml/lit on 31-10-2014 and 4-11-12014. Also the flowering orchard was subjected to spray of chlorpyriphos $20 \% \mathrm{EC}+$ metalaxyl $8 \%+$ mancozeb (Twin) on 26-11-2014 (Table 4). However, there was meagre mortality on subsequent days. The observed number of frames with bee cluster ranging between 7.50 to 8.00 indicated healthy population of $A$. mellifera bees inside the hives. Further, there was no incidence of any pest and disease throughout the monitoring period.

Farmer at the location Chanda was well aware of beekeeping management. All the insecticidal sprays mentioned above were given at dusk (late evening). Also he restricted to minimum (three) sprays to maintain the bee fauna during flowering period of pomegranate. Preventive care was also taken to close the bee colony gates for the period of $24 \mathrm{hrs}$ after spray interventions. 
Table 3. Insecticides used at M.P.K.V., Rahuri during experimental period (OP/SP carbamates/neonicotinoids/ newer compounds other than neonicotinoids).

\begin{tabular}{llccc}
\hline & Insecticide & $\begin{array}{c}\text { Total no. of } \\
\text { sprays }\end{array}$ & $\begin{array}{c}\text { Per cent use } \\
\text { among group }\end{array}$ & $\begin{array}{c}\text { Per cent use among } \\
\text { total use insecticides }\end{array}$ \\
\hline & Triazophos & 6 & 11.11 & 4.32 \\
& Monocrotophos & 3 & 5.56 & 2.16 \\
OP compounds & Acephate & 1 & 1.85 & 0.72 \\
& Quinalphos & 7 & 12.96 & 5.04 \\
& Chlorpyriphos & 12 & 22.22 & 8.63 \\
& Malathion & 5 & 9.26 & 3.60 \\
& Dimethoate & 14 & 25.93 & 10.07 \\
& Dichlorvos & 2 & 3.70 & 1.44 \\
SP compounds & Profenophos & 4 & 7.41 & 2.88 \\
\hline \multirow{2}{*}{ Carbamates } & Lambda-cyhalothrin & 4 & 17.39 & 2.88 \\
& Deltamethrin & 10 & 43.48 & 7.19 \\
\hline \multirow{5}{*}{ Neonicotinoids } & Cypermethrin & 8 & 34.78 & 5.76 \\
& Fenpropathrin & 1 & 4.35 & 0.72 \\
\hline & Thiodicarb & 1 & 16.67 & 0.72 \\
& Carbosulfan & 5 & 83.33 & 3.60 \\
\hline & Clothianidin & 1 & 5.26 & 0.72 \\
& Acetamiprid & 1 & 5.26 & 0.72 \\
Newer compounds other & Thiamethoxam & 9 & 47.37 & 6.47 \\
than neonicotinoids & Imidacloprid & 8 & 42.11 & 5.76 \\
& Flubendiamide & 1 & 2.70 & 0.72 \\
& Lufenuron & 1 & 2.70 & 0.72 \\
& Emamectin benzoate & 4 & 10.81 & 2.88 \\
& Indoxacarb & 3 & 8.11 & 2.16 \\
& Spinosad & 6 & 16.22 & 4.32 \\
& Buprofenzin & 1 & 2.70 & 0.72 \\
& Fipronil & 17 & 45.95 & 12.23 \\
& Fenpyroximate & 1 & 2.70 & 0.72 \\
& Rynaxypyr & 2.70 & 0.72 \\
& Novaluron & 5.41 & 1.44 \\
\hline
\end{tabular}

Mortality of honey bees observed in front of colonies at Aalefata (Case III): Similar experiment was also conducted on the pomegranate orchard at Aalefata during 23-11-2013 to 28-02-2014. The data collected revealed that, the mean mortality of $A$. mellifera per day ranged between 0 - 28.33 dead bees/day.

The pomegranate orchard was sprayed six times as: Acetamiprid $20 \%$ SP) (Tata manik) on 24-11-2013; Carbosulfan $25 \%$ EC) + (Acephate $75 \%$ SP) + (Carbendazim + Mancozeb75 \% WP) [Marshal + Asataf + Saaf] on 28-11-2013; Monocrotophos + Bavistin (Chetak + Bavistin) on 17-12-2013; (Dichlorvos $76 \%$ EC + Mancozeb $75 \%$ WP) (Nuvan + M-45) on 4-012014; (Carbosulfan $25 \%$ EC) + (Acephate $75 \%$ SP) + (Carbendazim $50 \%$ DF) [Marshal + Asataf + Bavistin] on 02-02-2014; (Carbosulfan 25\% $\%$ EC) + (Acephate $75 \%$ SP) + (Carbendazim $50 \%$ DF) (Table 5).

The bee mortality was meagre on subsequent days. The observed number of frames with bee cluster ranged between 7.00 to 8.00 , indicating healthy population of $A$. mellifera inside the hives. Further, there was no disease incidence throughout the monitoring period.

Pomegranate grower was aware of bee pollination and beekeeping management. Since the farmer was owner of all three colonies of $A$. mellifera. All the insecticidal sprays were made at dusk period (late evening). Also he tried to reduce unnecessary sprays to maintain the bee flora during flowering of pomegranate. All colony gates were closed for the period of $24 \mathrm{hrs}$. The internal feeding with artificial diet before spray also supported the reduction of bee exposure on the sprayed crop which minimized the hazards of pesticides. The managed shifts in the flowering of pomegranate also ensured the food resource for bees.

The precautionary measures were taken by the farmer to reduce the pesticidal poisoning to honey bees at case II and III. This has been reflected in the meagre mortality of bees under the case II and III compared to case I. This clearly indicated that there should be cooperation between the growers and beekeepers regarding management of honey bee colonies and pesticide use from the point of view bee safety. The present findings are in conformity with the earlier suggestions i.e clear and regular communication between the grower and beekeeper is the best way to avoid the pesticide hazards with bees (Ellis et al., 2014). Many bee poisoning problems could be prevented by better communication and cooperation among the grower, pesticide applicator and the beekeeper (Krupke et al., 2014).Some workers mentioned different hazards and safeguards to bees in 
Table 4. Mortality of honey bees observed in front of colonies at Chanda (Case II).

\begin{tabular}{|c|c|c|c|c|c|c|c|c|}
\hline Interval in days & $\mathbf{A}$ & $\mathbf{B}$ & Mean & $\begin{array}{l}\text { Mortality / } \\
\text { day }\end{array}$ & $\begin{array}{l}\text { Mean number } \\
\text { of frames with } \\
\text { bee cluster }\end{array}$ & $\begin{array}{l}\begin{array}{l}\text { Date } \\
\text { of } \\
\text { spray }\end{array} \\
\end{array}$ & $\begin{array}{l}\text { Pesticide sprayed } \\
\text { (Active ingredi- } \\
\text { ent) }\end{array}$ & $\begin{array}{l}\text { Diseases } \\
\text { observed }\end{array}$ \\
\hline $14-10-2013$ to $16-10-2013$ & 18 & 25 & 21.50 & 7.17 & 8 & & & Nil \\
\hline $17-10-2013$ & 3 & 2 & 2.50 & 2.50 & 8 & & & Nil \\
\hline $18-10-2013$ to $23-10-2015$ & 46 & 19 & 32.50 & 5.42 & 8 & & & Nil \\
\hline $24-10-2013$ & 4 & 0 & 2.00 & 2.00 & 8 & & & Nil \\
\hline $25-10-2013$ to $30-10-2017$ & 17 & 6 & 11.50 & 1.92 & 8 & & & Nil \\
\hline $31-10-2013$ & 4 & 10 & 7.00 & 7.00 & 8 & $\begin{array}{l}31-10- \\
2013\end{array}$ & $\begin{array}{l}\text { Nimbecidine } \\
\text { (Azadirachtin } \\
0.03 \% \text { ) }\end{array}$ & Nil \\
\hline $1-11-2013$ to $2-11-2013$ & 15 & 13 & 14.00 & 7.00 & 8 & & & Nil \\
\hline $3-11-2013$ to $5-11-2020$ & 17 & 21 & 19.00 & 6.33 & 8 & $\begin{array}{l}04-11- \\
2013\end{array}$ & $\begin{array}{l}\text { (Nimbecidine) } \\
\text { Azadirachtin } \\
0.03 \%\end{array}$ & Nil \\
\hline $06-11-2013$ & 0 & 1 & 0.50 & 0.50 & 8 & & & Nil \\
\hline $7-11-2013$ to $8-11-2013$ & 3 & 0 & 1.50 & 0.75 & 8 & & & Nil \\
\hline $09-11-2013$ & 3 & 3 & 3.00 & 3.00 & 8 & & & Nil \\
\hline $10-11-2013$ to $11-11-2013$ & 10 & 6 & 8.00 & 4.00 & 8 & & & Nil \\
\hline $12-11-2013$ & 3 & 2 & 2.50 & 2.50 & 8 & & & Nil \\
\hline $13-11-2013$ to $14-11-2013$ & 3 & 2 & 2.50 & 1.25 & 8 & & & Nil \\
\hline $15-11-2013$ & 5 & 2 & 3.50 & 3.50 & 8 & & & Nil \\
\hline $16-11-2013$ to $17-11-2013$ & 6 & 4 & 5.00 & 2.50 & 8 & & & Nil \\
\hline $18-11-2013$ & 3 & 0 & 1.50 & 1.50 & 8 & & & Nil \\
\hline $19-11-2013$ to $21-11-2013$ & 22 & 4 & 13.00 & 4.33 & 8 & & & Nil \\
\hline $22-11-2013$ & 5 & 0 & 2.50 & 2.50 & 8 & & & Nil \\
\hline $23-11-2013$ & 4 & 5 & 4.50 & 4.50 & 8 & & & Nil \\
\hline $24-11-2013$ & 1 & 1 & 1.00 & 1.00 & 8 & & & Nil \\
\hline $25-11-2013$ & 0 & 0 & 0 & 0.00 & 8 & & & Nil \\
\hline $26-11-2013$ & 9 & 1 & 5.00 & 5.00 & 8 & $\begin{array}{l}26-11- \\
2013\end{array}$ & $\begin{array}{l}\text { Twin } \\
\text { (Chlorpyriphos } \\
20 \% \text { EC+ metalax- } \\
\text { yl } 8 \%+\text { Mancozeb) }\end{array}$ & Nil \\
\hline $27-11-2013$ & 0 & 2 & 1.00 & 1.00 & 8 & & & Nil \\
\hline $28-11-2013$ & 4 & 1 & 2.50 & 2.50 & 8 & & & Nil \\
\hline $29-11-2013$ & 7 & 6 & 6.50 & 6.50 & 8 & & & Nil \\
\hline $30-11-2013$ & 3 & 1 & 2.00 & 2.00 & 8 & & & Nil \\
\hline $01-12-2013$ & 5 & 3 & 4.00 & 4.00 & 8 & & & Nil \\
\hline $02-12-2013$ & 5 & 4 & 4.50 & 4.50 & 8 & & & Nil \\
\hline $03-12-2013$ & 2 & 1 & 1.50 & 1.50 & 7.5 & & & Nil \\
\hline $04-12-2013$ & 3 & 0 & 1.50 & 1.50 & 7.5 & & & Nil \\
\hline $05-12-2013$ & 9 & 3 & 6.00 & 6.00 & 7.5 & & & Nil \\
\hline $06-12-2013$ & 0 & 7 & 3.50 & 3.50 & 7.5 & & & Nil \\
\hline $07-12-2013$ & 0 & 1 & 0.50 & 0.50 & 7.5 & & & Nil \\
\hline $08-12-2013$ & 4 & 3 & 3.50 & 3.50 & 7.5 & & & Nil \\
\hline $09-12-2013$ & 5 & 1 & 3.00 & 3.00 & 7.5 & & & Nil \\
\hline $10-12-2013$ & 0 & 4 & 2.00 & 2.00 & 7.5 & & & Nil \\
\hline $11-12-2013$ & 5 & 1 & 3.00 & 3.00 & 7.5 & & & Nil \\
\hline
\end{tabular}

$\mathrm{A}, \mathrm{B}=$ A. mellifera colonies, Foraging crop: pomegranate

applying insecticides to crops in bloom (Mader and Adamson, 2012; Hoven et al., 2013; May et al., 2015).

\section{Conclusion}

The coordination between beekeepers and farmers and some preventive and safety measures helps to lower down the probable bee loss. The area where pesticide use is frequent, proper care should be taken to prevent exposure of bee to insecticide and to maintain honey bee hives. Proper precautionary measures (insecticidal sprays were given at late evening hr, minimum and need based use of chemical sprays, use of safer insecticides, closing the bee colony gates for the period of 24 $\mathrm{hr}$ and internal feeding with artificial diet before spray) 
Table 5. Mortality of honey bees observed in front of colonies at Aalefata (Case III).

\begin{tabular}{|c|c|c|c|c|c|c|c|c|c|c|c|}
\hline $\begin{array}{l}\text { Interval in } \\
\text { days }\end{array}$ & $\mathbf{A}$ & B & C & SD & Mean & $\begin{array}{l}\text { Mor- } \\
\text { tality } \\
\text { /day }\end{array}$ & $\begin{array}{l}\text { Mean num- } \\
\text { ber of } \\
\text { frames with } \\
\text { bee cluster } \\
\end{array}$ & $\begin{array}{l}\text { Date } \\
\text { of } \\
\text { spray }\end{array}$ & $\begin{array}{l}\text { Pesticide } \\
\text { sprayed } \\
\text { (Trade } \\
\text { name) } \\
\end{array}$ & $\begin{array}{l}\text { Active ingredient } \\
\text { of pesticide } \\
\text { sprayed }\end{array}$ & $\begin{array}{l}\text { Diseases } \\
\text { observed }\end{array}$ \\
\hline $\begin{array}{l}23-11-2013 \text { to } \\
25 / 12 / 2013\end{array}$ & 12 & 18 & 16 & 3.05 & 15.33 & 5.11 & 8 & $\begin{array}{l}24-11- \\
2013\end{array}$ & Tata manik & $\begin{array}{l}\text { (Acetamiprid } 20 \% \\
\text { SP) }\end{array}$ & Nil \\
\hline $\begin{array}{l}26 / 11 / 2013 \text { to } \\
1 / 12 / 2013\end{array}$ & 38 & 22 & 15 & 11.79 & 25.00 & 4.17 & 8 & $\begin{array}{l}28-11- \\
2013\end{array}$ & $\begin{array}{l}\text { Marshal + } \\
\text { Asataf }+ \text { Saaf }\end{array}$ & $\begin{array}{l}\text { (Carbosulfan } 25 \% \\
\text { EC) }+(\text { Acephate } \\
75 \% \text { SP })+ \\
(\text { Carbendazim }+ \\
\text { Mancozeb } 75 \% \\
\text { WP })\end{array}$ & Nil \\
\hline $\begin{array}{l}2 / 12 / 2013 \text { to } \\
7 / 12 / 2013\end{array}$ & 9 & 4 & 2 & 3.61 & 5.00 & 0.71 & 8 & & - & & Nil \\
\hline $\begin{array}{l}8 / 12 / 2013 \text { to } \\
15 / 12 / 2013\end{array}$ & 5 & 7 & 4 & 1.53 & 5.33 & 0.76 & 8 & & - & & Nil \\
\hline $\begin{array}{l}16 / 12 / 2013 \text { to } \\
21 / 12 / 2013\end{array}$ & 20 & 28 & 37 & 8.51 & 28.33 & 5.67 & 8 & $\begin{array}{l}17-12- \\
2013\end{array}$ & $\begin{array}{l}\text { Chetak + } \\
\text { Bavistin }\end{array}$ & $\begin{array}{l}\text { Monocrotophos + } \\
\text { Bavistin }\end{array}$ & Nil \\
\hline $\begin{array}{l}22 / 12 / 2013 \text { to } \\
26 / 12 / 2013\end{array}$ & 9 & 16 & 3 & 6.51 & 9.33 & 1.56 & 8 & & - & & Nil \\
\hline $\begin{array}{l}27 / 12 / 2013 \text { to } \\
3 / 01 / 2014\end{array}$ & 4 & 8 & 2 & 3.06 & 4.67 & 0.67 & 8 & & - & & Nil \\
\hline $\begin{array}{l}4 / 01 / 2014 \text { to } \\
8 / 01 / 2014\end{array}$ & 13 & 15 & 5 & 5.29 & 11.00 & 2.20 & 8 & $\begin{array}{l}\text { 04-01- } \\
2014\end{array}$ & $\begin{array}{l}\text { Nuvan + M- } \\
45\end{array}$ & $\begin{array}{l}\text { (Dichlorvos 76\% } \\
\text { EC + Mancozeb } \\
75 \% \text { WP) }\end{array}$ & Nil \\
\hline $\begin{array}{l}9 / 01 / 2014 \text { to } \\
14 / 01 / 2014\end{array}$ & 12 & 14 & 8 & 3.06 & 11.33 & 2.27 & 8 & & - & & Nil \\
\hline $\begin{array}{l}15 / 01 / 2014 \text { to } \\
20 / 01 / 2014\end{array}$ & 9 & 11 & 3 & 4.16 & 7.67 & 1.28 & 8 & & - & & Nil \\
\hline $\begin{array}{l}21 / 01 / 2014 \text { to } \\
25 / 01 / 2014\end{array}$ & 7 & 3 & 2 & 2.65 & 4.00 & 0.67 & 8 & & - & & Nil \\
\hline $\begin{array}{l}26 / 01 / 2014 \text { to } \\
1 / 02 / 2014\end{array}$ & 6 & 6 & 2 & 2.31 & 4.67 & 0.67 & 7.67 & & - & & Nil \\
\hline $\begin{array}{l}2 / 02 / 2014 \text { to } \\
7 / 02 / 2014\end{array}$ & 8 & 13 & 6 & 3.61 & 9.00 & 1.50 & 7.67 & $\begin{array}{l}02-02- \\
2014\end{array}$ & $\begin{array}{l}\text { Marshal + } \\
\text { Asataf }+ \\
\text { Bavistin }\end{array}$ & $\begin{array}{l}\text { (Carbosulfan 25\% } \\
\text { EC) }+(\text { Acephate } \\
75 \% \text { SP) }+ \\
\text { (Carbendazim 50\% } \\
\text { DF) }\end{array}$ & Nil \\
\hline $\begin{array}{l}8 / 02 / 2014 \text { to } \\
15 / 02 / 2014\end{array}$ & 22 & 11 & 18 & 5.57 & 17.00 & 2.43 & 7.67 & & - & & Nil \\
\hline $\begin{array}{l}16 / 02 / 2014 \text { to } \\
20 / 02 / 2014\end{array}$ & 11 & 14 & 2 & 6.25 & 9.00 & 1.80 & 7.67 & & - & & Nil \\
\hline $\begin{array}{l}21 / 02 / 2014 \text { to } \\
24 / 02 / 2014\end{array}$ & 15 & 18 & 6 & 6.25 & 13.00 & 3.25 & 7 & $\begin{array}{l}21-02- \\
2014\end{array}$ & $\begin{array}{l}\text { Dursban }+ \\
\text { Nuvan }\end{array}$ & $\begin{array}{l}\text { (Chlorpyriphos } \\
20 \% \text { EC)+ } \\
\text { (Dichlorvos } 76 \% \\
\text { EC) }\end{array}$ & Nil \\
\hline $\begin{array}{l}24 / 02 / 2014 \text { to } \\
28 / 02 / 2014\end{array}$ & 17 & 23 & 16 & 3.79 & 18.67 & 3.73 & 7 & & - & & Nil \\
\hline
\end{tabular}

$\mathrm{A}, \mathrm{B}$ and $\mathrm{C}=$ Names of $A$. mellifera colonies, Foraging crop: pomegranate, ${ }^{* *} 1$. The farmer was aware of bee keeping and bee health, 2. The farmer was owner of bee colonies, 3. Colony gates were closed during day after spray (management practices by farmer): to avoid exposure to toxicant, 4. All sprays were made at dusk period (late evening), 5 . All observation were recorded during $1000 \mathrm{hr}$ of day, 6 . After recording observation the dead bees from trays were discarded, 7. Colony strength: 8 frames (approx. 5000-7000 bees), 8. Normal mortality for a colony with 60000 bees/colony: $<100$ bees/day

helps to lower down exposure of bees to insecticides.

\section{ACKNOWLEDGMENTS}

The first author sincerely acknowledges the Post Graduate Institute, Mahatma Phule Krishi Vidyapeeth, Rahuri, Ahmednagar (Maharashtra), Country- India for her Ph. D. research. Thanks are also due to the Head and Professor of Department of Entomology for providing field and laboratory facilities during the course of this investigation.

\section{REFERENCES}

Abou-Shaara, H. F. (2014). The foraging behaviour of honey bees, Apis mellifera: A review. Vet. Med-Czech,59:1-10

Abrol, D. P. (2009). Honey bees and pesticides. Bees and beekeeping in India. Kalyani Publishers, New Delhi, Pp. 559-577

Anonymous (2013). Pesticide poisoning in honey bees. TNAU Agritech portal, http://agritech.tnau.ac.in/ farm_enterprises/fe_api_pesticidepoisoning.html

Blazyte-Cereskiene, L., Vaitkeviciene, G., Venskutonyte, S. and Buda, V. (2010). Honey bee foraging in spring oilseed rape crops under high ambient temperature con- 
di-tions. Zemdirbyste-Agriculture, 97: 61-70

Celli, G., Porrini, C., Baldi, M. and Ghigli, E. (1989). Pesticides in Ferrara Province: two years monitoring with honey bees (1987-1988). Ethology Ecology \& Evolution, 3: 111-115

Delabie, J., Bos, C., Fonta, C. and Masson, C. (1985). Toxic and repellent effects of cypermethrin on the honeybee: Laboratory, glasshouse and field experiments. Pesticide Sci., 16, 409-415

Ellis, J. D., Klopchin, J., Buss, E. Fishel, F. M., Kern, W. H., Mannion, C., McAvoy, E. Osborne, L. S., Rogers, M. Sanford, M., Smith, H., Stansly, P., Stelinski, L. and Webb, S. (2014). Minimizing honey bee exposure to pesticides. University of Florida publication, Pp. 14, $\mathrm{http}: / /$ edis.ifas.ufl.edu.

Hoven, L., Sagili, R. and Johansen, E. (2013). How to reduce bee poisoning from pesticides. A Pacific Northwest Extension Publication, Oregon State University, PNW 591, Pp. 6-7

Joshi, N. C. and Joshi, P. C. (2010). Foraging behaviour of Apis spp. on apple flowers in a subtropical environment. New York Science Journal, 3: 71-76

Klein, A. M., Vaissiere, B. E., Cane, J. H., Steffan-Dewenter, I., Cunningham,S. A., Kremen, C. and Tscharntke, T. (2007). Importance of pollinators in changing landscapes for world crops. Proc. Biol. Sci., 274: 303-313

Krupke, C. H., Hunt, G. and Foster, R. E. (2014). Protecting honey bees from pesticides. Purdue University Extension Publication, E-53-W, Pp.1-5

Mader, E. and Adamson, N. L. (2012) Invertebrate conservation fact sheet: Organic -approved pesticides minimizing risks to bees. The Xerces Society for Invertebrate Conservation publication, Pp.1-6

May, E., Wilson, J. and Isaacs, J. (2015). Minimizing pesticide risk to bees in fruit crops. Extension Bulletin Michigan State University- E3245, Pp. 1-16

Mayer, D. F and Johansen, C. A. (1983). Occurrence of honey bee (Hymenoptera: Apidae) poisoning in eastern Washington. Environ. Entomol., 12: 317-320

Mayer, D. F. Johansen, C. A. and Baird, C. R. (1999). How to reduce bee poisoning from pesticides: PNW518, A Pacific Northwest Extension Publication, Washington, Pp. 2-3

McDonald, J. H. (2014). Handbook of Biological Statistics ( $3^{\text {rd }}$ ed.) Saprky House Publishing, Baltimore, Maryland, 157-164

Muthuraman, M. (2000). Impact of pesticides on honey bees. In: Training manual for the summer school on
'Environmental impact of pesticides in agro-ecosystem: Assessment and Abatement'. May 3-23, Pp. 40-44

Pashte, V. V. and Kulkarni, S. R. (2015). Role of Pollinators in Qualitative Fruit Crop Production: A Review. Trends in Biosciences, 8: 3743-3749

Pashte, V. V. and Said, P. P. (2015). Honey bees: Beneficial robbers! Int. J. Agric. Sci. Res., 5: 343-352

Perez, J. L., Marino, H., Miguel, S., Llorente, J. and Meana, A. (2001). Easy ways to determine honey bee mortality using dead-bee traps. J. Apic. Res., 40: 25-28

Pongthep, A. (1990). Pesticides and beekeeping. In: Beekeeping in Asia. FAO publication. Pp. 121

Porrini, C., Sabatini, A. G., Giritti, S., Ghini, S., Medrzycki, P., Grillenzoni, F., Bortolotti, L., Gattavecchia, E. and Celli, G. (2003). Honey bees and bee products as monitors of the environmental contamination, Apicta, 38:63-70.

Potts, S. G., Biesmeijer, J. C., Kremen, C., Neumann, P., Schweiger, O. and Kunin, W. E. (2010). Global pollinator declines: trends, impacts and drivers. Trends in Ecology and Evolution, 25: 345-353

Puskadija, Z. Stefanic, E., Mijic, A., Zdunic, Z., Paradzikovic, N. and Florijancic, T. (2007). Influence of weather conditions on honey bee visits (Apis mellifera carnia) during sunflower (Helianthus annus L.) blooming period. Poljoprivreda, 13: 230-233

Radunz, L., Smith, E. S. C. and Darwin (1996). PesticideHazards to honey bees. Agnote, 12: 1-4

Schen-bayo, F. and Goka, K. (2016). Impacts of pesticides on honey bees. In book: Beekeeping and Bee Conservation- Advances in Research, Chapter: 4, Publisher: InTech Open Science, Editors: Emerson D. Chambo, pp.77-97 DOI: $10.5772 / 62487$

Steen J. M. V. and Dinter, A. (2007). A monitoring study to assess the acute mortality effects of indoxacarb on honey bees (Apis mellifera L.) in flowering apple orchards. Pest Manag. Sci., 63: 1095-1099

Suhail, S., Guez, D. and Belzuness, L. P. (2001). Toxicity of imidacloprid and its metabolites in A. mellifera. In: Hazards of pesticides to bees, INRA publication, Paris, Pp. 121-126

Tan, K., Yang, S., Wang, Z., Radloff, S. E. and Oldroyd, B. P. (2012). Differences in foraging and broodnest temperature in the honey bees Apis cerana and A. mellifera. Apid-ologie, 43: 618-623

VanEgelsdorp, D., Hayes, J., Underwood, R. M. and Pettis, J. (2008). A survey of honey bee colony losses in the U.S., fall 2007 to spring 2008. PLos ONE, 3: 1-6 e4071. doi:10.1371/journal.pone.0004071 